\title{
Social Entrepreneurship in Terms of Woman Being Top-Level Manager in Public Institutions: Ankara State Opera and Ballet (ASOB) Case
}

\author{
Ilkben Akansel \\ Artvin Coruh University Hopa Economics and Administrative Faculty, Hopa/Artvin, Turkey
}

\begin{abstract}
Today, it is said that the participation women's labor force has been increased. According to the last announced statistics of Turkish Statistical Institute (TSI), the participation of labor force in higher graduates (university) rate is $83.9 \%$ in men, $70.7 \%$ in women. Although, the numbers indicate a brilliant picture, the problems of women's labor force are continuing enduringly. Women's working life is interrupted by discrimination and segregation which made an impression in whole society and pushed them back. This case, especially, is found its counter in top level management in the public institutions. Discrimination and segregation can be seen both in the public sector and private sector. It is thought that discrimination and segregation may be seen lesser in public sector. However it is not true. Maybe these circumstances can be seen in the public sector, especially in the art sector, one of which is very dependent on government's applications. Due to the fact that the government's political aspects directly affects the working conditions and managerial positions. While doing this study, it will try to put forward a picture of Ankara State Opera and Ballet (ASOB), if those concepts mentioned (discrimination \& segregation) have not occurred in this institution's top-level management. This study will be analyzed starting with discrimination and segregation concepts why women face some difficulties in working life. Then, it will be examined by the relationship between discrimination and segregation and hegemony and ideology concepts. Consequently, it will try to understand why women entrepreneurship comes in the most important place in ASOB rather than the top managerial positions.
\end{abstract}

Keywords: woman, discrimination, segregation, entrepreneurship, art

\section{Introduction}

Today, the problems faced by women in the working life have been continuing. The theories in the labor force market are based on their analysis of the debating on education, age, marital status, etc.. However, no matter what they argue about women working, all are affected by two obstacles. Virtually, these two obstacles give influence for all thoughts related to women's labor force.

Basically, there are two obstacles to prevent participation of women's labor force: (1) Discrimination: It is raised by "gender" concept and constituted by men hindering women professionally; (2) Segregation: Works

Ilkben Akansel, Assistant Professor, Dr., Business and Management Department, Artvin Coruh University Hopa Economics and Administrative Faculty, Hopa/Artvin/Turkey.

Correspondence concerning this article should be addressed to Ilkben Akansel, Artvin Coruh Universitesi Hopa Iktisadi ve Idari Bilimler Fakultesi, 08600 Hopa/Artvin/Turkey. E-mail: iakansel@yahoo.com; iakansel@artvin.edu.tr. 
are segregated as "manly works" and "womanly works".

The type of discrimination, which is our main concern, is "gender" originated. Gender discrimination is to treat two equal people basically for their sexualities (Anker \& Hein, 1985, p. 74). "Gender” originated means which roles, duties, circumstances etc. can be attributed and divided between women and men. Discrimination and segregation which are directly affected working women can be understood by roles and duties for men and some roles and duties for women. Historically, the roles and duties of women were sometimes intertwine, but frequently differ from each other. Many factors like natural, economical, religious, and social factors, could act in this circumstance. Women are affected by these circumstances historically, will face different types of discrimination and segregation in modern working life.

The first is discrimination "can be seen as either different payment for the same job or the individuals who have same productivity will be having different jobs which would be paid different" (Lordoğlu \& Özkaplan, 2003, p. 224).

It is well known that discrimination and segregation can occurred especially in payments. "Not only the level of wages but also the method of pay seems to differ systematically by gender” (Jirjahn \& Stephan, 2004, p. 683).

Different kinds of payment can be seen much more in informal economies. Different levels of wages and different methods of payments could not occur in public sector. Gender is not affected by wages and payments. However, it does not mean that any discrimination and segregation could not occur by different kinds of thoughts which are caused by gender roles. As it will seen the onward chapters, due to the fact that ASOB is a public institution, different kinds of payment cannot be seen. However, horizontal and vertical segregation can be seen enormously.

Man-dominant ideology is a barrier in front of women for many reasons. Either being hired for a job or continuing a career, men are treated as preferential. For example, it can be identified as discrimination in an occupation where people who have the same education-level between women and men, but they just have different sexes. The main opinion is that home-domesticated works and the roles of taking care of children are for women whereas earning money for men (Ecevit, 2000, p. 157).

The second is segregation that occupations are divided into a man job and a woman job. It is called occupational stratification developed by Bergmann (Lordoğlu \& Özkaplan, 2003, p. 224). It is divided into two sections per se:

- Horizontal segregation: Segregation in an occupation group or segregation in one obvious sector. It means that jobs are divided as a men work and as a women work;

- Vertical segregation: Hierarchical segregation in an institution (Ecevit, 2001, p. 158).

Pointing as feminist economics, in horizontal segregation works are divided as women work and men work, in vertical segregation, for example, women work as chief, on the contrary of, men work as executive director, manager etc..

"Men and women differ not only in their physical attributes and reproductive function but also in many other characteristics, including the way they solve intellectual problems” (Kimura, 1992, p. 118).

"At the least, 'the sexed' relative possession of such an attribute is unknown, so as things stand, the female shortage cannot be attributed to gender differences” (Abra \& Valentine-French, 1991, p. 236).

"The genetic obstacle is the claim that women are, in some ways, simply not suited to certain activities and are destined to fail compared with men” (Cameron, 2003, p. 910). 
Nevertheless, it should not be forgotten that genetic obstacles cannot prove that women and men have inequal talents to do some jobs. Under the framework of this study, it cannot be said that men are able to create new plays rather than women. Because creating a new grief needs to have an open mind, creativity and bring different kind of pieces, such as steps and music harmonically, and in ASOB, women create a new play better than men under this frame.

In this study, the author will start to explain why women workers push back in the working life first of all by the mediation of discrimination and segregation concepts. Then, the author will try to look the idea which lies down behind why women are pushed back in terms of ideological way. So, in here, Louis Althusser's and Antonio Gramcsi's thoughts will help us. This study aims to find the relationship between ideology and hegemony and women's pushing back at the second step in working conditions, especially in terms of top administrative level. According to our opinion, in public sector, discrimination and segregation can occur much more than in private sector. This study will examine whether these circumstances can be seen or not both in general and in private ways in ASOB.

\section{A General View of a Top-Level Manager}

This study is setting “discrimination” concept out, it will analyze why woman employees wouldn't be brought to the top-level management in public institutions. Here, especially, "vertical segregation" concept will enlighten people. Our case is Ankara State Opera and Ballet (ASOB). In our opinion, although, this institute is called as "art sector" and appears as a marginal one, it is not different with any other institutions because of being a public institution.

Regarding all of these, entrepreneurship is a very important concept which covers the working life. Especially, it will be enlightened much more clearly by discrimination and segregation in terms of women entrepreneurship. This study is much more interested in the status which undertakes as a choreographer instead of women working in the top-level management with respect of women entrepreneurship.

Such as art, which is a creation of its own, highly feels itself with the respect of women entrepreneurship. Firstly, it is seen that ASOB is a production of the revolution which has a claim to make difference in all fields by the magnificent genius of Mustafa Kemal Atatürk. This claim is aroused by modernization.

Historically founded as a part of modernization ASOB for an interpretational institution of opera, ballet has the status of "General Directorate" in the middle of 2000's. In mentioned years, it was removed by "General Directorate" to the "Directorate".

As it has been known as the history of the institution, women has been worked as "general choreograph" which is a medium-level managerial position. It is the first time a woman had been appointed to the "General Directorate" which is the top-level management status of the institution in the mid 2000.

At this point, it is not said definitely that looking only one position, but the institution has been partly collapsed the prescience by the way of horizontal and vertical segregation. The discrimination in woman-job and man-job has been partly demolished by appointing a woman, because it is a mostly seen job which can be done by men- “General Directorate” job.

Likewise, the regulation of vertical segregation has been destroyed by appointing a woman in a top-level management. However, it is not recalled that an appointment, which was applied once in the institution, does not sign that there is no discrimination and segregation in the institution.

Apparently, if the executive part is put up, the main concern of this study "woman entrepreneurship in the 
art sector" will be raised clearly. This study means women entrepreneur to be a "choreograph".

One of the common ways that workers increase their earnings is to invest in human capital to increase their productivity. For workers in most occupations, it has been well established that a large part of this investment in human capital takes place through attendance at formal schooling (see Freeman, 1986 for excellent summary of literature). With respect to occupations in arts, however, schooling may not increase workers' earnings to the same extent as in other occupations. (Filer, 1990, p. 15)

Formal schooling plays an important role in getting a job. Exclusively, well-educated artists are necessary in art sector. According to this study's framework, a dancer should not be considered that not educated in dance field, especially in ballet art. Besides, in our opinion, gathering with being a choreographer and ballerina identifications have much more great importance to creating a new play. Because, seeing where dancers show their mimics is as convenient as the spirit of the grief or which steps can explain better what the music says etc.. So, all those kinds of circumstances need to have a good dancer who knows the rules of dance very well and also an artist creates new things with an open-mind.

\section{Entrepreneurship/Social Entrepreneurship}

\section{Social Entrepreneurship in Terms of Women in ASOB}

Ballet art may be defined as music and dance steps display in harmonically. The choreographer is the one who makes it real. It is observed that women choreographers are much more than men choreographers quantitatively. Especially, the new performances which were created in the last years have a woman signature, such as, Harem (Hareem), Calikusu (Scrubbird), and the performances by Modern Dance Company.

However, in these performances, we can see the traces of Ottoman Era effect commonly, because all those performances are basically against to classical ballet spirit. In our opinion, the politics of the institution cannot be differentiated by the political eras. All of these are related with Antonio Gramsci’s "hegemony” concept.

According to Gramsci's hegemony,

A society does not only be administrated by force but also be administrated by convince. Thus, a society learns how their administrators look the circumstances and they will look the circumstances from their administrators. The advantage of a group will obviously see by 'domination' and 'intellectual leadership'. Hereby, dominant group can control the against-group which is probably a voluteer for destroy theirselves. (Gramsci, 1971; Arrighi, 2000, pp. 54, 55)

With respect to our topic, which is not exactly related in this study, those kinds of performances are being affected by the right-hand side politics. Now, we must look at the concept of entrepreneurship about our topic. Firstly, the entrepreneurship concept must be understood.

Coming from French "entreprendre", entrepreneur concept is translated to Turkish by "entrepreneur" (in Turkish: girişimci). As a concept, "entrepreneur" is not only a complicated one. It is complicated in developed countries as well. In economic field, it was first used by French Richard Cantillon in 1730's and in the 19th century by John Stuart Mill. Entrepreneur concept has been continuing to use in many fields like sociology, psychology, and economics in the 20th century (Çetindamar, 2002, p. 33).

According to the entrepreneurship theory which was appeared in the 20th century, the entrepreneur is the one who makes innovation. In other words, entrepreneur is the person who observes the opportunities and finding makes them real to bear every risk. (Schumpeter, 1961, Schumpeter, 2000; Westhead \&Wright, 2000; Çetindamar, 2002, p. 33)

Adam Smith, the establisher of the liberal economics, identified entrepreneur with capitalist. In this term, 
it has been accepted that the entrepreneur is the person who directs the workplace and gains money by such business (Çetindamar, 2002, pp. 33, 35).

Essentially, being a dancer, an opera artist, and a musician is one of the branches of working in ASOB. Although being an artist type which was written in above is being an occupation, on the contrary being an entrepreneur must not have been required by gender. As it is seen what Cameron (Cameron, 2003) said:

There are distinct patterns of female activity in comparison with males: for example a successful female rock/pop composer is very unlikely to be working in a collaborative environment in a same-gendered 'band', while this is a dominant mode for males. Well-known females in jazz are much more likely to be singers than instrumentalists or composers. Such findings may constitute a prima facie case for discrimination. This is reconsidered in the conclusion. (p. 905)

Because creating a product requires a creative talent. According to our opinion, creating new things are given a model role by gender roles. Thus, for example, creating a new play can be achieved by women in ASOB much better. This study does not claim that only women are able to create new plays contrary to men are not have a capable to create new plays, however, a middle-top executive level are occupied by women, much more plays would have done by them. Besides, one cannot forget that dominant man ideology is an obstacle in front of woman who maybe wants to be a top-manager.

While there have been notable woman conductors, such as Imogen Holst and Nadia Boulanger (who was the first ever woman conductor in 1937), and there are currently women conducting major orchestras, such as the Halle in the UK, they are not in elite of superstar conductors, which is a heavily cartelized system which is not easy to break into, and also tend to be occasional junior conductors rather than in full positions. Indeed, the Picture of Imogen Holst conducting, shown in Fuller (1994), is with the Snape Maltings Training Orchestra which has an 'exception that proves the rule quality', however worthy the aforesaid outfit may be. Another heavily cartelized position is the virtuoso pianist. Only six of the 37 pianists featured on the CD sampler (Philips, 1998) from the project of 'classic' 20s century piano performances are women, an even then they are the less well-known names. (Cameron, 2003, p. 907)

As one can see at above, some artists' position can be cartelized by men. Here, some ideas can be upgraded. The first one is that some artistic positions are suitable by men because of the stereotype that men are capable of doing some jobs better due to their sexualities.

What should be considered about the booking sex differentials must be remembered that there are both natural differences and cultural and society differences.

Thinking that a man and a woman have inequality by genetic obstacles, one can remember that gender built by culture is tried to show the difference between man and woman.

The difference between the girl and the boy babies' are universal on the contrary how these girls and boys will become a woman and man are formed by the expectations where it can be changed by the conditions of geographical, time, class, urban/rural way of life. (Elçik, 2010, p. 4)

Despite that some scientists are against to the difference between sex-gender using for natural/biological and artificial/social. [...] According to this, the determination of sex is also a product of a fiction 'his-tory' and sex is a political and cultural interpretation of body. (Butler, 2008, p. 193; Elçik, 2010, p. 4)

As a claim that the determiner of the differences between genders, it has been proved that whether sex or hormones are affected or not. "Money and Ehrhardt who are very important names studying in this subject have proved that raising the styles based on sex is much more fetal hormones have no effect for determiner of creation of sex identification” (Elçik, 2010, p. 5). 
Defenders of the genetic hypothesis might admit that both social and genetic factors place women artists at a disadvantage. Under this dual view female artistic achievements will not be scattered randomly. Environmental factors might account for the variation in women's achievements, while genetic factors could still account for a generally lower level of achievement. This dual view, to the extent it places deceive weight on genetic factors, then suggests the following test: if we find superior female artistic accomplishments when we find superior incentives for women to produce, we should conclude that circumstances are the major obstacle holding women back and reject the dual view. If superior incentives for women still result in superior male production, we find support for the dual view. (Cowen, 1996, p. 95)

Looking at the genetic hypothesis, it can be said that no man has superior creatures more than women in both artistic fields and the other working fields. Moreover, the circumstances pushing women back in the art sector, working women in ASOB can be more voluntary in order to be a choreographer. Because if ballet art is a visual one, so indeed, women dancers can give much more importance to the shape of their body, the visage of their dances than men, their creatures may be much more visible than men can do.

Also, when it should be considered again the subject of discrimination, Becker-style one must be the first one to look at (Cameron, 2003).

Becker-style discrimination can break down into four broad categories: selection biases in training and education; customer or consumer against employee; worker against fellow worker; and employer against worker. [...] Let us now to consumer discrimination. For a start, males are a large part of musical consumption and, as such, may experience disutility from the mere presence of a female on an unacceptable instrument, to the point where they refuse to spend or attend. [...] Thus, even if women do gain equal encouragement and access in instrument playing their horizons may be selectively limited. (pp. 911, 912)

Looking at Becker-style discrimination, as consumer or customer employee, in ASOB maybe not in top-managerial positions, but middle-level position being an entrepreneurship could not be seen as such a discrimination. The reason of this is necessary in creating a new play which has a talent and imaginary mind, women can be an entrepreneurship much more than men.

As seen, entrepreneurship is largely related to the development of the economics. But, the thoughts of who is the entrepreneur or what is the theory of entrepreneurship would exactly change with the theory of Joseph Schumpeter.

However, Australian scientist named Joseph Schumpeter "found the theory of entrepreneurship early in the 20th century” (Çetindamar, 2002, p. 35).

"According to the point of view of Schumpeter, economics is a system but changing come from internal, do not come from external as neo-classics said".

The entrepreneur is the one who makes all these changes real. According to Schumpeter's view, there are five different entrepreneur attitudes:

- producing a new goods or service;

- improving a new method;

- forming a new market;

- finding a new raw material source;

- re-constituing the industry.

As in Schumpeter's definition, entrepreneurship title covers making innovation which is not a permanent status. Entrepreneur is an entrepreneur if only he/she makes innovation. In other words, entrepreneurship is an apprehension and behavior way (Çetindamar, 2002, p. 35).

So, we can describe the entrepreneurship by the way of our topic, choreographs are very exactly to concur the theory of Schumpeter's. Because a choreographer is a person not only to produce a new service, but also to 
form a new market for his/her new choreography as well.

Known as ASOB's services in the art sector, its products are art ones. So, the institution must both display the classical performances and create new performances. Making a different for its products, the institution has been creating the performances which are based on the topic “Ottoman”. Considering the politic area of the last years of Turkey, it is not puzzled for one who knows the events in the politics.

In the 21th century,

Developments in production, know-how and communication technologies are perceived to simplify of founding firms and spreading new markets. Governments, financial organizations and capital owners present resources for people who have entrepreneur soul and new ideas to found new jobs and to provide employment. (Karabulut, 2009, pp. 11, 12)

The primary problem here is whether political area supports the institution or not. Or if political area supports the institution, what the degree of it, so how this supporting is affected the woman entrepreneurship is the question of making an interest of our mind.

If one who wants to understand why a government supply or does not supply an art institution, he/she can understand firstly Louis Althusser's ideology. According to Althusser's theory, the practice of society and ideology are nested within each other. "If one can remember that ideology dispatches the thoughts which are related about irregular facts on the contrary, the real thoughts related about real facts" (Kazanc1, 2006, p. 10).

The fact is that how the ideology of the politicians affects the entrepreneurship of woman. This debate actually has a simple answer: Art would have been founded by a part of modernization. In the early years of the Turkish Republic, it could achieve its mission partly. However, after 1950's against-modernization thought would be surrounded by largely everywhere. So, it is not able to say that the art sector would not be affected by this fact. Besides, maybe the art sector is the most affected one.

In terms of women entrepreneurship in the art sector, it is raised by the choreography based upon the Ottoman life performances. Also, in the early years of the institution, it had been wanted that people's mind would change by the mediation of the art. Through the years, the audiences of the institution have been the people who are well-educated and have middle-high income.

The ways of creating a job idea is to observe the goods and the services of people whose consumption are high-level (Titiz, 1994, p. 28). So, the women entrepreneur of the institution tries to create the performances for those people. After all, it has been said that describing the choreograph women in the institution as a "social entrepreneur".

Social entrepreneurship concept is searched by two different opinion evolve. The first is "non-profit organizations" theory.

Its main argument is the activity area of social entrepreneurs which is called "third sector"-volunteer sector. According to Young, "non-profit entrepreneurs are the people who found new organizations, applying new programmers and methods, bringing new services, re-orienting the activity area of the organizations which are in a bad situation” (Young, 1990, p. 162; Güler-Kümbül, 2010, p. 45). “The other opinion is accepting social entrepreneurship under the entrepreneurship, states not limiting sector that private sector which seeks profit also can be make social activities” (Prabhu, 1999, p. 45; Güler-Kümbül, 2010, p. 45).

Social entrepreneurs resemble traditional entrepreneurs in many ways. "For example, founding a new organization, attributing for socio-economic developments, determining the chances, to be innovator and decided are the mutual characteristics of two types of entrepreneurs. But, the main difference of social entrepreneurs with private sector entrepreneurs is social entrepreneurship are ambitiousness in solving 
problems and creating social worth (Dees, 1998a, p. 1; and Bhawe, Jain, \& Gupta, 2006) and this is the mission of their organizations. Shortly, gaining profit and cashing in for social entrepreneurs occur as product of at the end of their job. Aimed actually is making a social value and difference” (Güler-Kümbül, 2010, p. 46).

The social entrepreneur which is related to our topic is the one of the types written in the below:

- Artist;

- Professional;

- Spiritual;

- Researcher;

- Independence;

- Right-wing;

- Hegemonies;

- The one who wants to earn revenue.

Artists are the people who obtain satisfaction directly from the creative work. These types are divided as architects and poets. Each wants to see creating new things, producing, and developing the things which they have found. The architect is a member of private sectors and the poet is a member of non-profit organizations (Güler- Kümbül, 2010, p. 115).

The social women entrepreneur in the institution can be described as "artist” type.

Entrepreneurs are the ones who develop their own business and make it larger. They spend physical energy, and they can be patient for working long hours. The biggest factor of this working is the internal motivation (Arrkan, 2004, p. 49).

The choreograph woman in the institution, both an entrepreneur and a social entrepreneur. Because creating a production they only want to enrich more people and enrich the audiences of ballet art. So, they are entrepreneurs. The choreographer does not earn any extra-payment except her salary. They try to get more people for the institution, so they are social entrepreneurs.

We cannot say any discrimination or segregation in choreograph women. Because to be a choreographer, actually is seen as much more of woman work. And it is not a top-level management position. According to our opinion, women are more successful than men in the management "choreograph" which means to manage and organize a performance at the beginning from the last scene. The reason of this is:

"The reasons why women are successful on entrepreneurship have been investigated by many researchers. According to one of those which are Hatlen's research that women entrepreneur is successful because of these reasons:

- they are proportionally democratic and humanistic in the management strategies;

- they are more participator in human relationships;

- Against to have contentious characteristic necessity as an entrepreneur they are vigilant on take risk, sensible, creative, and confidental on their sense" (Arıkan, 2004, p. 287).

\section{Conclusions}

Patriarchal system works in everywhere and in everything of our lives. It is seen especially in working life of women. Every sector has a special problem of its own. However, women are affected by these problems largely. One of these problems is "discrimination” which is equal educated, equal profession but only sex-based women and men are treated differently. The other is "segregation" for which jobs are divided as men jobs and 
women jobs. Both of these sources are the patriarchal ideology.

Of course, our sample as if it looks like a marginal sector, ASOB cannot divide the general aspect. The main reason of this is approximately in 60 years of its history, women would not have been appointed to the top-level manager as a "General Directorate". It shows that patriarchal ideology came into surface and people’s mind and women could not manage the top-level management for many years.

On the contrary, a medium-low manager who creates performances, the choreographer shows both horizontal segregation and vertical segregation. It is a vertical segregation, because more women work as choreographers in the institution. It is a horizontal segregation, because the best performances are being created by women. In our opinion, it is directly related to social entrepreneurship of women.

The reason is that women are much more capable to create attractive performances. But, it is seen that a problem in creating those kinds of attractive performances. In the last years, it has been creating much more of an appealing of Imperial Ottoman Era projects. According to our opinion, it is caused by the hegemony's ideology. So, it can be said that hegemony is everywhere and inside of every work. The art sector cannot segregate itself from him.

It can be said that because of ASOB which could not segregate itself from hegemony, although it is better than other institutions, women working in the institution are affected by both "discrimination" and "segregation”. Both problems show themselves especially in the top-level management.

In spite of this, middle-low directorate of a choreographer could not have been affected by this problem. It has two reasons. The first is a choreographer that is seen as a women job. The second is a choreographer who can be seen as a social entrepreneur. Generally, women make new products such as Ottoman era profiles. So, on the one hand, these kinds of productions are the counter of classical ballet art spiritual, on the other hand, they have risen the audiences of the art sector.

As a conclusion, in terms of women, social entrepreneurship in the institution is very effective. And it would not be impressed by discrimination and segregation in the middle-top management. But, the-top management of the institution could not be seen as appropriate for women, social entrepreneurship and women are not being assigned for this position.

\section{References}

Abra, J., \& Valentine-French, S. (1991). Gender differences in creative achievement: A survey of explanations. Genetic, Social and General Psychology Monoraphs, 117, 235-284.

Anker, R., \& Hein, C. (1985). Why third world employees prefer men? International Labour Review, 124(1), 73-89.

Arıkan, S. (2004). Girşimcilik: Temel Kavramlar ve Bazı Güncel Konular (Entrepreneurship: The basic concepts and some actual subjects). Ankara: Siyasal Kitabevi.

Arrighi, G. (2000). Uzun Yirminci Yüzyıl, Para, Güç ve Çağımızın Kökenleri (The long twentieth century: Money, power, and the origins of our times). Ankara: İmge Kitabevi.

Bhawe, N., Jain, T. K., \& Gupta, V. K. (2006). The entrepreneurship of the good samaritan: A development framework to understand social entrepreneurship using insights from qualitative study. Retrieved May 16, 2006, from http://ssrn.com/abstract=902685

Butler, J. (2008). Cinsiyet Belası (Gender Trouble). İstanbul: Metis Yayınevi.

Cameron, S. (2003). The political economy of gender disparity in musical markets. Cambridge Journal of Economics, 27, 905-917.

Cowen, T. (1996). Why women succeed and fail, in the arts. Journal of Cultural Economics, 20(2), 93-113.

Çetindamar, D. (2002). Türkiye'de Girişimcilik (The entrepneurship in Turkey). İstanbul: TÜSİAD Yayınları.

Dees, G. (1998). The meaning of social entrepreneurship. The Kaufmann Center for Entrepreneurial Leadership and Ewing Marion Kaufmann Foundation Working Paper. 
Ecevit, Y. (2000). Kadın-Erkek Eşitliğine Doğru Yürüyüş: Eğitim, Çalışma Yaşamı ve Siyaset (Walking through the equality to woman-man: Working life and the politics). İstanbul: TÜSİAD Yayınları.

Elçik, G. (2010). Biyolojinin Marifetleri (The talents of biology). İkisat Dergisi, 514, 3-10.

Filer, R. K. (1990). Arts and academe: The effect of education on earnings of artists. Journal of Cultural Economics, 14(2), 15-40.

Gramsci, A. (1971). Selections from the Prison Notebooks. New York: International Publishers.

Güler-Kümbül, B. (2010). Sosyal Girişimcilik (The social entrepreneurship). Ankara: Efil Yayınevi.

Jirjahn, U., \& Stephan, G. (2004). Gender, piece rates and wages: Evidence from matched employer-employee data. Cambridge Journal of Economics, 28, 683-704.

Karabulut, T. (2009). Girişimcilik ve Sürdürülebilirliği (The entrepreneurship and its maintainability). İstanbul: Papatya Yayıncilik.

Kazanc1, M. (2006). Althusser, İdeoloji ve İdeoloji İle İlgili Son Söz (Althusser: Ideology and the last word about the ideology). İstanbul Üniversitesi İletişim Fakültesi Dergisi, 24, 1-20.

Kimura, D. (1992, September). Sex differences in the brain. Scientific American (pp. 118-125).

Lordoğlu, K., \& Özkaplan, N. (2003). Çalışma İktisadı (The Working Economics). İstanbul: Der Yayınları.

Prabhu, G. N. (1999). Social entrepreneurial leadership. Career Development International, 4(3), 140-145.

Schumpeter, J. A. (1961). The theory of economic development. New York: Oxford Press.

Schumpeter, J. A. (2000). Entrepreneurship as innovation. In R. Swedberg (Ed.), Entrepreneurship: The Social Science View. Oxford: Oxford University.

Titiz, T. (1994). Girişimcilik: Ulusça Zenginliğe Açılan Kapı (The entrepreneurship: The door opening to the prosperity with whole nation). İstanbul: İnkılâp Kitabevi.

Tyler, C. (1996). Why women succeed, and fail, in the arts. Journal of Cultural Economics, 20, 93-113.

Westhead, P., \& Wright, M. (2000). Advances in entrepreneurship. Celtenham, UK: Edward Elgar.

Young, D. R. (1983). If not for profit, for what?: A behavioral theory of the nonprofit sector based on entrepreneurship. Massachusetts: Lexington Books. 